\title{
Empowering Women Through Corporate Social Responsibility: A Feminist Foucauldian Critique
}

\author{
Lauren McCarthy \\ Royal Holloway University of London
}

\begin{abstract}
Corporate social responsibility (CSR) has been hailed as a new means to address gender inequality, particularly by facilitating women's empowerment. Women are frequently and forcefully positioned as saviours of economies or communities and proponents of sustainability. Using vignettes drawn from a CSR women's empowerment programme in Ghana, this conceptual article explores unexpected programme outcomes enacted by women managers and farmers. It is argued that a feminist Foucauldian reading of power as relational and productive can help explain this since those involved are engaged in ongoing processes of resistance and self-making. This raises questions about the assumptions made about women and what is it that such CSR programmes aim to empower them 'from' or 'to.' Empowerment, when viewed as an ethic of care for the self, is better understood as a self-directed process, rather than a corporate-led strategy. This has implications for how we can imagine the achievement of gender equality through CSR.
\end{abstract}

KEY WORDS: gender, empowerment, corporate social responsibility, Foucault, feminism

$\mathrm{F}^{\mathrm{s}}$ eminism is enjoying a resurgence in popular culture (Koffman \& Gill, 2013), and feminism's goals of gender equality and equity appear to be mirrored in a growing number of corporate social responsibility (CSR) programmes and policies which claim to empower women in businesses' value chains (Coleman, 2010; Cornwall \& Anyidoho, 2010). These policies contain phrases such as "Empower a woman and you feed a community," "Gender economics is smart economics," and "Women are our most valuable untapped resource," echoed throughout international bodies such as the United Nations (UN) and the World Bank, and within national government policy (Prügl, 2015; Roberts, 2015). The potential for 'empowered' women to contribute to social, economic, and environmental sustainability is a well-worn rhetoric in development circles, now imported into CSR (Cornwall \& Anyidoho, 2010). Accordingly, businesses such as Coca-Cola, Vodafone, Walmart, H\&M, General Mills, and many others, are engaging in 'women's empowerment' projects as part of their CSR efforts in value chains (ICRW, 2016). After many years of inattention to gender in CSR scholarship and practice (Marshall, 2011; Spence, 2016), women's empowerment through CSR is now an established facet of international development (Grosser, McCarthy, \& Kilgour, 2016; ICRW, 2016). 
The focus on women as carriers of global development and sustainability is related to the longstanding debate within business ethics, particularly within Business Ethics Quarterly, about whether there are 'feminine' ethics (Dobson \& White, 1995), how they are related to feminist ethics (Derry, 1996; Liedtka, 1996), and how such ethics might be observed in women and men within organisations (Burton \& Dunn, 1996; Wicks, Gilbert, \& Freeman, 1994; Wicks, 1996). In particular, feminist ethics, with its focus on relationality and cooperation, has been positioned as cultivating more socially responsible business (Wicks et al., 1994; Wicks, 1996), with women (although not exclusively) exuding a power to change the world for the better (White, 1992). To this end, recent corporate attention on empowering women in value chains, particularly in the global South, mirrors these early approaches to feminism, business ethics, and social change. As I will argue, this adoption of some of the (mis)assumptions of feminist ethics into CSR programmes is not without concern.

CSR is defined here as a set of practices and policies enacted by private businesses with the ostensible aim of first, limiting negative impacts of businesses (doing no harm), and second, contributing to society through activities that benefit people and planet (Gond \& Moon, 2011). While business remains a dominant actor within this phenomenon, it is worth stressing that other organisations are relevant (and powerful) to the context, including governments, non-governmental organisations (NGOs), civil society, and the beneficiaries of CSR practices themselves (Gond \& Moon, 2011; Grosser, 2009). The diversity of 'gendered' CSR practices is reflected in an increased awareness of women in the global South as salient stakeholders (Karam \& Jamali, 2013) and investment in women's empowerment programmes, ${ }^{1}$ which are often forms of multi-stakeholder initiatives or public-private partnerships involving corporations, NGOs, governments, and funding bodies such as the IMF (Bexell, 2012; ICRW, 2016). These new configurations of governance, with respect to women and CSR, are beginning to be addressed in scholarship (Bexell, 2012; Roberts, 2015). Yet there remain few studies on the operationalisation of gendered CSR in the form of women's empowerment programmes (Tornhill, 2016a). Gendered CSR makes explicit tensions over imposing cultural changes from lead companies in the global North, onto men and women in the global South (Adanhounme, 2011; Khan \& Lund-Thomsen, 2011).

The overall aim of this article, therefore, is to explore the concept of women's empowerment as a relevant, yet contested, concept for business ethics and CSR scholars. In its current usage within CSR, empowerment entails a discourse of caring, cooperative women "lifting themselves and others out of poverty" (WEF, 2013) through individual micro-entrepreneurship enterprises, facilitated by business (Roberts, 2015). This is very different from the original women's and civil rights movement's conceptualisation, where empowerment is a socio-political process, and where shifts in power are central to change, for individuals and across social groups (Batliwala, 2007). Examining this disjuncture, and providing windows into the realities of CSR empowerment programmes, I offer two vignettes taken from research in the Ghanaian cocoa value chain. Here, the subject positions that a women's empowerment discourse creates for the men and women involved is contrasted with the embodied, gendered experiences of Ghanaian farmers and cooperative 
workers. ${ }^{2}$ To explore why the discourse fails to live up to the reality I turn to feminist Foucauldian ideas of gender, power, and freedom.

Deconstructing the term 'women's empowerment' indicates two broad conceptual concerns: gender and power. In this article I draw on a conceptualisation of gender not just as a social construction, practice, or performance, but as a process which encapsulates all of these dimensions of human existence (Linstead \& Pullen, 2005; Pullen, 2006; Pullen \& Knights, 2007). Inspired by the writings of Foucault and by feminist thinkers who have applied this work to gender theory (e.g. Grosz, 1994), Linstead and Pullen (2005: 292) argue that "gender is not the construction or outcome of a performance but is immanent within those performances making them productive of new molecular connections in the meshwork of identity." This translates into an understanding of gender as something fluid, and an ongoing process of self-making (Butler, 2004; Linstead \& Brewis, 2004). This is important in relation to the notion of women's empowerment since it problematises the idea of 'women' or 'woman' as a static category of identity, role, or even performance. The rhetoric of a hierarchal binary between men and women has previously been deconstructed by feminist organisational scholars studying leadership (e.g. Acker, 1990; Bowring, 2004), but this scrutiny has not yet fallen on the assumptions made about the men and women involved in CSR programmes.

In speaking of empowerment it is necessary to explore what is meant by 'power' (Hardy \& Leiba-O'Sullivan, 1998). I take inspiration from Michel Foucault (1978, $1980,1982,1986,1994)$ and the ways his work has been interpreted by many feminist scholars in relation to gender (Butler, 1997; Hayward, 2000; McNay, 1992; Pullen, 2006; Sawicki, 1991). Power is relational (power is everywhere and enacted by all), and productive (a site of ongoing negotiation over meaning) (Foucault, 1982, 1986). In particular, Foucault's later works (1982, 1985, 1986, 1987, 1994) present an intriguing picture of the role of the individual in power relations, and how individuals create their own 'conditions of freedom' within strategic games of power play (Crane, Knights, \& Starkey, 2008). Opposed to theories which treat women as a homogenous group, with fixed identities labouring under patriarchal structures, post-modern feminist scholars have drawn upon Foucault's theory of power due to its potential for human agency, resistance, and alternative understandings of gendered power relations (Butler, 2004; Kelan, 2010; Kondo, 1990; McNay, 1992; Pullen, 2006; Sawicki, 1991). As this article aims to show, applying a feminist Foucauldian understanding of power and gender to CSR in the global South, specifically in relation to the outcomes of CSR women's empowerment projects, contributes an alternative perspective on what is fast-becoming a CSR 'fashion.' It reignites a conversation within Business Ethics Quarterly regarding how feminist approaches might see women as individuals, yet also recognise the relational, interconnected nature of systems of gender inequality and power in which CSR initiatives take place (Derry, 1996).

I therefore provide two contributions to CSR theory regarding development initiatives with this article. First, I contribute to the study of gender, business ethics, and CSR by unpacking the notion of women's empowerment in corporate-led programmes in the global South. I contrast the current discourse that surrounds women's 
empowerment alongside accounts of the beneficiaries and champions of these programmes acting in unexpected or paradoxical ways. Women become synonymous with gender and with static roles as carer, mother, and entrepreneur. Their innate power is co-opted into a business case narrative which requires women to remain in these roles. Yet as I show in my vignettes, women (and men) may resist these positions and contribute to unintended programme outcomes.

Second, I contribute to theory on women's empowerment and CSR by accounting for such paradoxical outcomes through feminist Foucauldian theory on power and freedom. I explain how the concepts of subjectivation and freedom are useful for exploring the meaning of empowerment for CSR and business ethics scholars. These concepts stress the recursive relationship between human beings, power relations, and social change, and emphasise how individuals constantly negotiate and resist 'gender' (Butler, 2004; McNay, 2000), thus problematising the notion of 'women's' empowerment. Further, a feminist Foucauldian reading of freedom, which presents human beings as 'subjects' who are both free and constrained within power relations (Crane et al., 2008; Foucault, 1987; Hayward, 2000; Hirschmann, 2002) is best understood as a process in which workers' own capability for struggle and resistance is paramount (Foucault \& Deleuze, 1977). Again, this challenges prior articulations of feminine/feminist ethics as focused on women as a group, and ethics lying in the collective (Dobson \& White, 1995; White, 1992), and the manifestation of this in CSR practice. Instead, I argue, the current focus of businesses striving to empower women through CSR may not always be possible, or indeed, welcome, when freedom is better understood as self-making, and the female and male 'beneficiaries' of CSR reconceptualised as active agents therein.

The article is structured as follows: I first introduce the phenomenon of CSR women's empowerment programmes. I explore the concept of empowerment, highlighting four ways in which the current narrowing of a neoliberal approach to empowerment fails to live up to the original concept's ideal. I then introduce my own research on CSR women's empowerment, entailing a case study from the Ghanaian cocoa industry. I draw on two vignettes to illustrate the ways in which CSR women's empowerment programmes in the global South are often more complex and problematic than the narrative around them allows. Following this, I use a feminist Foucauldian lens to answer two pertinent questions relating to the vignettes, and CSR and women's empowerment more generally: why might women resist empowerment efforts, and what do corporations seek to empower these women from or to? I finish with a discussion on what a feminist Foucauldian lens on women's empowerment adds to theoretical approaches to CSR and business ethics, particularly around the notion of 'freedom,' and suggest some ways in which businesses may wish to rethink their gender equality efforts.

\section{WOMEN'S EMPOWERMENT THROUGH CSR}

Can CSR programmes be a vehicle for women's empowerment? This question is not easily answered, since divergent opinions exist regarding how female emancipation can be won (Prügl, 2015), and empirical evidence on how marginalised people 
(such as women workers) experience CSR remains scarce (Ansari, Munir, \& Gregg, 2012). Yet the ubiquitous 'business case' for women's empowerment persists (e.g. Coleman, 2010; Pellegrino, D’Amato, \& Weisberg 2011). This narrative of women's empowerment has been well-recounted by others (Koffman \& Gill, 2013; Wilson, 2011), so I only introduce it briefly here. The logic follows that if girls are empowered through education (cf. Nike's Girl Effect) ${ }^{3}$ or empowered as adults within value chains (cf. Coca-Cola's 5by20) 4 then women's "entrepreneurial potential" will be "unleashed," creating more sustainable business and "helping families and communities prosper" (Coca-Cola, 2012). It is argued that women, as mothers, carers, and community-influencers can provide routes out of poverty not just for themselves but for families, communities, and even nations (World Bank, 2011).

The World Economic Forum argues that women's advancement can help tackle "five global problems of: demography, leadership, food security and agriculture, sustainability and scarcity, and conflict" (WEF, 2013: 3). Coleman (2010) compiles evidence for the business benefits of investing in women's empowerment, citing initiatives by Nike, Unilever, and the World Bank, and supported by consultancy reports (e.g. Pellegrino et al., 2011) and NGOs (e.g. Oxfam, 2012). Behind the slogans there are some compelling empirics, for example, on how increasing women's empowerment can lead to increased productivity on farms (Coles \& Mitchell, 2011) or how empowered women are more likely to send their children, especially girls, to school (Quisumbing, Payongayong, \& Otsuka, 2004). There is also growing evidence that increasing women's empowerment leads to national economic growth (Duflo, 2012; World Bank, 2011). Yet the evidence that links this to organisational performance is relatively scant in comparison to the strength of the rhetoric (ICRW, 2016). Furthermore, impact assessments of women's empowerment within value chains reveal mixed results (Rohatynskyj, 2011; Tornhill, 2016a, 2016b), with unsurprisingly, corporate-sponsored evaluations yielding positive results (e.g. Yeager \& Goldenberg, 2012).

All of this is not to say that an evidence-base for businesses engaging in women's empowerment is not valuable, but that the rhetoric of a business case has potentially eclipsed the reality. Cornwall, Harrison and Whitehead (2007) write of "gender myths and feminist fables" within the gender and development sector. I contend that these are being incorporated non-reflexively into the CSR lexicon, especially regarding the business case for women's empowerment. Furthermore, concern has been raised over the moral legitimacy of businesses to engage in global governance (Bexell, 2012; Switzer, 2013) and the appropriateness of CSR activity as a means to promote gender equality: activity that stands accused of strengthening businesses' power in the global economy (Pearson, 2007). Corporate-led women's empowerment efforts, with Nike's Girl Effect advertisements the most heavily critiqued, are argued to position girls and women as "productive and contented workers in colonial enterprises" (Wilson, 2011: 316), "lifted out' of history and politics to be recast as individual entrepreneurial subjects" (Koffman \& Gill, 2013: 90). The structural and institutional factors which mean women continue to face multiple economic, social, and political inequalities are conveniently erased from the twenty-first century, neoliberal narrative of women's empowerment (Cornwall, 2007; Koffman \& Gill, 2013; Roberts, 2015; Wilson, 2011). 
Many feminist analyses of women and/or gender with relation to business' role in society would find this co-optation of women's empowerment unsurprising, given the complicity of capitalism, and more recently the advent of CSR, with a patriarchal system where historically men have power over women (Elson \& Pearson, 1981; Pearson, 2007). Thus, the question of whether business, and CSR, can empower women within systems where they are already being exploited, appears to be redundant. Numerous empirical studies make this point, such as cases which document the beating and sexual harassment of women workers by male supervisors in Kenyan flower value chains (Hale \& Opondo, 2005), or less overtly the gender-blindness of CSR codes of conduct, and auditing, which do not recognise the specific needs of women workers and effectively shut out their concerns from regulatory structures of power (Barrientos, Dolan, \& Tallontire, 2003).

Women employed in value chains can sometimes earn better incomes, learn new skills, and gain confidence and autonomy (Maertens \& Swinnen, 2010). Thus, to argue that market economies always work against women is misleading, but the quality of work affects to what extent employment can considered empowering (Kabeer \& Mahmud, 2004). Generally, women's work continues to be under-valued in both status and pay (Pearson, 2007), and leaves few economic options, as women continue to juggle the 'triple shift' of paid work, housework, and care work (Waring, 1988). Many thus question the concept of choice regarding women's employment within the value chains where CSR is found (Wilson, 2011). Are women free to turn down a low-paid, unsafe job when their options are limited (Drebes, 2014)? Over the last forty years a significant body of work has shown how women have been a disposable resource for business (Pearson, 2007), with the illusion of personal economic choice, and women and girls' economic necessities, keeping industries stocked with workers (Reiman, 1987). Interestingly, the rise in female employment witnessed in the Middle-East is often predicated on new economic opportunities for business (Karam \& Jamali, 2013), whilst other aspects of equality, such as sexual freedom, remain untouched (Syed \& Van Buren, 2014). The gap between economic, and social and political equalities, and the role of CSR in addressing this, is thus pertinent to the question of empowerment.

\section{The Concept of Empowerment}

It therefore pays to interrogate some of the assumptions behind these dichotomous positions: those who claim women's empowerment is possible through CSR, and those who critique both the method (CSR programmes) and the agent (business). Before turning to my own accounts of women's empowerment in the cocoa value chain, let us explore what empowerment is taken to mean in both approaches. According to the World Bank, empowerment is "the process of enhancing an individual's or group's capacity to make purposive choices and to transform these choices into desired actions and outcomes" (World Bank in Cornwall, Gideon, \& Wilson, 2008: 3). CSR women's empowerment programmes most often focus on the individual woman as an entrepreneur (Wilson, 2011), i.e., on economic empowerment, aiming for the specific outcome of wealth accumulation (Cornwall et al., 2007; Kabeer, 1999; Roberts, 2015). This is usually facilitated by an intervention, led by an NGO or by a company, which 
provides training or microfinance. Power is therefore viewed as something someone 'has' (Lukes, 1974/2005) and women's empowerment is achieved when their innate 'power within' (tied to their identity as women) (Cornwall, 2007) is drawn out by an external party, such as a business or NGO.

In contrast to this entrepreneurial framing of empowerment, Rowlands (1995) defines empowerment as

the process by which people, organisations or groups who are powerless (a) become aware of the power dynamics at work in their life context, (b) develop the skills and capacity for gaining some reasonable control over their lives, (c) exercise this control without infringing upon the rights of others and (d) support the empowerment of others in the community (Rowlands, 1995: 103).

There are four points pertinent to this broader definition of empowerment that are worth considering in application to CSR. The first is that empowerment is best understood as an ongoing process (Kabeer, 1999) with many cyclical stages involved (Summerson-Carr, 2003). Even here, however, the concept of a process can be co-opted into a series of steps that external parties, such as companies, can enact to achieve employee or stakeholder empowerment (Hardy \& Leiba-O'Sullivan, 1998). The problem is that as a cyclical, messy process, empowerment takes time and can fail more often than succeed - a frustration that few NGOs can manage and budget for (Cornwall et al., 2007, 2008) and that few corporations can understand given business' short-term focus on results (Mena, de Leede, Baumann, Black, Lindeman, \& McShane, 2010).

Second, empowerment is about power in that it is a socio-political process (Batliwala, 2007) during which people become aware of power relations and then exercise some control over these (Freire, 1970; Rowlands, 1995). This process, however, can unfold for different people at different times and in different ways, complicating the notion of a 'tidy' process of social change (Cornwall, 2007). As I argue in the remainder of the article, however, assuming that the beneficiaries of women's empowerment programmes are powerless (Rowlands, 1995: 103) is problematic since it presupposes a particular understanding of power as something held by one group (often men, and/or the ruling class) over another (often women, and/or the poor). This echoes a recurring problem with the conceptualisation of power and agency in much CSR and development literature (Drebes, 2014).

Third, whilst economic empowerment (wealth accumulation and control of finance) is one aspect of empowerment and economic resources, in the form of equal pay for example, it is by no means indicative of empowerment as a whole (Cornwall, 2014; Kabeer, 1999) and presents problems in how to measure and evaluate women's empowerment (Mena et al., 2010). Many indicators are overly reliant on economic measures, or the representation of women in different roles and occupations (Cornwall et al., 2007; Kabeer, 1999), a problem also observed in evaluations of organisational diversity (Ahonen, Tienari, Meriläinen, \& Pullen, 2014). For example, a recent report which claims to explore how women may thrive in the workplace turns out to simply measure women's representation in 
different top management roles (Mercer, 2016). Focusing on counting the women is just one basic indicator of gender in organisations, and has very little to do with empowerment in a fuller sense (Kabeer, 1999).

Fourth, empowerment involves groups of people, or individuals within society acting not just as individual entrepreneurs but as social beings in cohort with others (Batliwala, 2007; Cornwall et al., 2008). This echoes discussions of relationality in business ethics and stakeholder theory, where the isolation of traditional leadership (Liu, 2017; Painter-Morland, 2008; Uhl-Ben, 2011), especially around business ethics and accountability (Freeman \& Liedtka, 1997; Painter-Morland, 2006), has been critiqued for ignoring the social ties that bind us. This chimes with the critique of a neoliberal notion of empowerment which treats women as atomised entities. Empowerment, however, whilst entailing an internal process of self-awareness, or consciousness raising, requires others. It is difficult for groups of marginalised people to make changes to their lives working alone, especially when those groups are implicated in profit-driven, transnational value chains (Freire, 1970; Summerson-Carr, 2003). Conversely whilst often women are forced to work in groups during CSR empowerment programmes (Tornhill, 2016a), as we explore in the next sections, this raises questions about which women, in which groups, and why we assume they 'should' work together (Cornwall, 2007; Yuval-Davis, 1994).

\section{PROBLEMATISING EMPOWERMENT: INSIGHTS FROM GHANA}

I here introduce vignettes from my own research into this area. Over the last four years I have been involved in evaluations and studies around a women's empowerment programme within the Ghanaian cocoa value chain. This programme involves a British company which makes chocolate from cocoa; a Ghanaian cocoa cooperative which buys the cocoa from smallholder farmer members; a British NGO partner which advises on the programme; and hundreds of individual Ghanaian cocoa farmers. ${ }^{5}$ Since 2013 I have collected data on this partnership and the programme, through document analysis, observations in the field, group discussions, and in-depth unstructured interviews and participant-led drawing (McCarthy \& Muthuri, 2016). ${ }^{6}$

The initial research project involved the production of 48 participant drawings, over 80 hours of observations, 23 in-depth interviews with staff and women farmers, and analysis of 120 internal and external documents relating to the programme. Here I present two vignettes drawn from this larger body of empirical work. Vignettes "are stories generated from a range of sources including previous research findings. They refer to important factors in the study of perceptions, beliefs and attitudes" (Hughes, 1998: 381). Thus, my goal is not to provide evidence for an empirical article, but rather to provide accounts as windows into other worlds (Humphreys, 2005; VanMaanen, 1988), particularly those relating to the complex, processual, and unpredictable nature of empowerment and power. Indeed, Foucault uses vignettes in his discussions of philosophy (1977a), and they are particularly favoured within feminist research (Ramazanoglu \& Holland, 2002). Chaudhry (2009), in her ethnographic study into gendered violence in India, explains that vignettes allow her to adopt a dialogic approach to research, involving the embedding of direct quotations 
from participants, an indirect re-telling of their stories and opinions, and a unique means of embracing reflexivity into her interpretation of the social world. Following this method (e.g. Chaudhry, 2009; Humphreys, 2005; VanMaanen, 1988) my two vignettes are written in the first-person present tense to try and capture the unfolding of surprising and unexpected beliefs and behaviour of some of the women I encountered within a CSR women's empowerment programme. They illustrate some of the common problems regarding focusing on women's empowerment within a CSR context, echoed in empirical studies (e.g. Cornwall, 2007, 2014; Koffman \& Gill, 2013; Switzer, 2013; Tornhill, 2016a, 2016b). They enable me to identify salient assumptions regarding gender and CSR practices, and to start to pose questions around the unexpected ways in which CSR women's empowerment programmes play out. The vignettes provide a means of connecting the messiness of what I, and my participants, experienced in Ghana with the often-complex theories of feminist Foucauldians.

Cocoa, a non-indigenous crop, was introduced to Ghana by British colonisers and immediately positioned as a 'male crop' (Doss, 2002). ${ }^{7}$ Colonisation also introduced Western norms regarding gender, especially around marriage, divorce, and work (Clark, 1994; Duncan, 2010). These imported social rules have, over time, mixed with the varied regional cultures' different social roles for women and men (Clark, 1994). For example, the Asante ethnic group ${ }^{8}$ (to which many of those in my study belonged) is matrilineal, ${ }^{9}$ with women famously dominating market places and trading, partially because they were forced out of the cash-crop cocoa boom (Clark, 1994). In terms of gender relations, Clark (1994: 107) notes that within Asante culture there is a culture of individuation, "a value of personal autonomy and dignity," which means that women and men are used to working separately and dividing their assets and income. To some extent, Ghanaian women have greater freedoms than women in other Sub-Saharan African countries (Baden, Green, Otoo-Oyortey, \& Peasgood, 1994). Yet women are still expected to provide unpaid care work (often without men's help), and unpaid labour on the farm, while men are the main (and often sole) decision makers on the farm and at home (Clark, 1994).

Within cocoa farming, it is only in recent years that women could own their own land and engage in the industry (Clark, 1994). Men continue to dominate cocoa landownership (only $20 \%$ of registered cocoa farmers are women), which impacts upon women's ability to produce crops, sell them in their own name, and join cooperatives (Barrientos \& Bobie, 2016). The low numbers of female cocoa landowners belie the findings of my case study, and many others (see Barrientos \& Bobie, 2016), which show that women perform nearly half of all cocoa work required on farms. Yet women farmers face challenges in terms of getting access to land, fertilisers, pesticides, training, loans, and labour (Barrientos, 2013; Barrientos \& Bobie, 2016).

Within this context, the background of the vignettes is thus: The businesses, alongside a supporting NGO, have engaged in a women's empowerment programme for over twenty years. The programme had been mutually designed and instigated by the three partnership organisations, with initial help from an external international women's NGO. They aim to economically, socially, and politically empower farming women in the cooperative. This first took the form of leadership training 
and affirmative recruitment for Ghanaian women in the cooperative structure, and later, craft-based income training. Originally conceived as part of a microfinance project, the craft-based projects (typically making batik, soaps, notebooks, jewellery, or growing vegetables for the market) began with a pooling model: women would form business and savings groups together to share resources and receive a small revolving loan from the cooperative, which was encouraged to be used for craftbased micro-businesses, echoing many microfinance models (Hudon \& Sandberg, 2013). Women were to work in groups, which established a system of peer-scrutiny, encouraging women to pay back loans and into the communal 'pot' (Mayoux, 1999). The model also reflected the wider aims of the Ghanaian organisation, which being a cooperative, and as stated in their mandate, operated on principles of democracy, sharing, and fairness. Women were positioned as central to this ideal as they "hold the community together, they hold the society together" (interview with Coop staff member, 2013). I was repeatedly told by UK and Ghanaian management how women were more loyal to the cooperative than men were, and how through the women's empowerment programme they would market the cooperative to other women.

In 2013, an evaluation using surveys, group discussions, and participatory drawing workshops revealed that whilst the numbers of women in decision-making positions in the cooperative had grown, and some of those women reported feeling more confident, the economic empowerment programmes were not creating wealth for women (McCarthy \& Muthuri, 2016). The reasons for this included low uptake of training opportunities, variable quality in products for sale, a lack of markets for products, and a consequent high dropout rate of women. The evidence showed that women's time is taken up by unpaid care work and substantial unpaid cocoa farming tasks, leaving no time for honing additional new skills and craft production. Thus, women dropped out of groups, failed to market and sell their produce, and reported that they were struggling with tasks: "You know as women we are challenged. We are taking care of the home and everything else" (female farmer, focus group, 2013). In the vignettes below I offer insights into the research which begins to challenge some of the assumptions of much CSR theory which positions those in the global South as needy but thankful beneficiaries (Drebes, 2014), and women as compliant, cooperative agents of development (Cornwall, 2007).

\section{Vignette 1: Unexpected Resistance}

It's a hot, dry day as I arrive in Ghana and meet Ama and Shirley, Ghanaian local women, who have worked for over ten and three years respectively as gender managers on the women's empowerment programme at the cooperative. In a meeting room with my co-researcher, our research assistants, translator, and other cooperative staff, we discuss how we will organise the programme evaluation and workshops. I immediately like the way Ama and Shirley humourously square up to reticent colleagues in our initial research meeting who are either unenthused by the women's empowerment projects, or are sceptical about the need to carry out research. They are both educated about, and have plentiful experience of working on, gender and development issues. They are also the only female managers in the whole cooperative, which reflects the extremely male-dominated environment of cocoa suppliers. 
The next day we begin carrying out interviews with local farming women. I am impressed with the ways in which both Ama and Shirley talk about empowerment and encourage the women we talk to. They enthuse about the need to hear from the women farmers themselves. I'm looking forward to starting the workshops out in the rural areas. However, over the next few days, Ama begins to withhold research funds. She avoids meetings and leaves Shirley trying to organise the rest of the research team. On two separate days, we are seriously delayed because Ama locks away the materials we need for fieldwork (such as paper and pens for drawing, and the cash for petrol). Another staff member whispers that they have not received any payment for the extra days they have worked whilst we are doing research: is this another delaying tactic from Ama? I email the NGO and chocolate company back in London and it's clear that this kind of resistance has taken place before: "She's a bully... but she gets things done" (interview with UK business manager, 2013). I want to speak to Ama and ask her what is going on, but she avoids my calls and we don't see her again during the fieldwork.

It's two weeks later and I am discussing the results of the evaluation with Shirley. As we go through some of the visual data from the workshops with farmers, we talk about the low uptake of craft training and more worryingly, how women are reporting very little, to no, income from the projects. Shirley continues to argue for craft-based training, despite this. I suggest that perhaps it would be better to help farming women to become better cocoa farmers, but she shakes her head. She maintains that the programme should open a shop: "A shop would give us internal funding... so we will be able to sustain the programme." Shirley's main concern seems to be to preserve the programme, rather than thinking about the aims of the programme itself. Pushing away/resisting the idea of farming training, as an alternative to crafts-training, Shirley comments that: "we should find something for the women to also do, that they have... financial independence" (interview with Shirley, 2013, my emphasis). I note in my observations journal that the farming women who are part of the empowerment programme are referred to by some cooperative staff as "wives of farmers," and that in nearly all meetings with village-level members, questions are directed to (and always answered by) male farmers. Women appear to exist outside the core business of cocoa farming. Economic empowerment through craft or small-scale agro-entrepreneurship is 'in,' and empowerment through more inclusive cocoa farming is 'out,' despite women already being cocoa farmers, and this seeming to have more potential as a lucrative livelihood stream.

As I sit with my co-researcher on the last evening of our visit to Ghana, we reflect on the different ways in which Ama and Shirley were resisting. My co-researcher posits that perhaps Ama and Shirley, struggling in a male-dominated organisation, fear for their jobs and thus stick with what they know best. Yet it had been made clear at the beginning that the gender programme would require more work and that their jobs were safe (indeed, Ama was eventually offered a leading role in a new, externally funded women's empowerment project) (correspondence with NGO, 2015). We are taken aback by the resistance these two influential women had exercised. Perhaps job protectionism was one aspect, but why would they try to 
scupper changes to the programme? Why are they so wedded to the idea of craft-based training, despite their own experiences, and now, as the evaluation shows that this approach isn't working?

\section{Vignette 2: All for One and None for All}

Spring is in the air as I approach the offices of the NGO partner, in London, a few weeks after my return from Ghana. The purpose of our meeting is to discuss the somewhat disappointing results of the women's empowerment programme evaluation. As well as running workshops with the farmers in Ghana, I've interviewed several on-the-ground staff at the cooperative, and therefore feel I have garnered a few additional insights into what is happening in the cocoa value chain, but need to understand further the results from the NGO manager's experience.

Settling in the office with coffee, I ask Olivia, the British NGO manager responsible for overseeing the programme, if I can take a look at the documentation around the setting up of the women's empowerment programme. It is clear that the initial plans stipulated for women to work in groups. Yet when talking to women during workshops, I found little evidence of them working collectively, preferring to work alone. I had asked some women why this was the case, but they did not want to explain. As British professionals, their refusal is puzzling to us because the risks associated with setting up microbusinesses, alone, are higher, and thus many of these women are unable to save alone to engage in enterprise. Trying to understand what is happening on the ground, and putting aside our own expectations, I turn to years of evaluation reports. I read about conflicts within groups around repayments of loans and where profit from the communal 'pot' would be spent (when, or if, there would be any) and how for some time now women farmers have reported back to the organisation that they do not like working in groups, preferring to work alone (internal documentation, dated 2002). As noted above this reflects local culture. I tell Olivia how Shirley is now struggling to manage women's expectations: "A lot of women came and requested individual loans, but the programme is not about loans, but that's what the women think.... It's getting out of hand" (interview with Shirley, 2013). Women are beginning to lose interest in the programme, which they say demands too much from them (focus group, 2013). The women don't want to work together, but working alone means they do not have the money to invest in their businesses, and they appear to become despondent. Olivia is concerned, because there is no more money for loans or individual financial support.

On a more positive note, I point out that there are encouraging statistics for the number of women moving into decision-making roles in the cooperative. For example, some women who had leadership training to become cocoa buyers, or cooperative leaders, said in the workshops that they "feel that anything a man can do, I can also do" (interview with woman farmer and cooperative leader, 2013). I do, however, have to tell Olivia that there are concerns amongst the board members that this is only empowering a certain kind of farming woman: "some of the stronger farmers marginalised the weaker ones" and "some of the really strong women from lower 
classes, and backgrounds, got one-by-one picked off and side-lined" by other women (interview with board member, 2013). Olivia sighs, and agrees that this is a problem, and that "it would be a mistake to say that the men outdid the women, ostracised them over there and took their jobs. But it wasn't like that." She tells me about attending an annual Fairtrade meeting in Ghana, where farmers are asked to decide on how to share the Fairtrade premium out amongst themselves. Olivia says that last year there was "an almost mass-riot" with farmers "standing up, shaking their fists" (conversation with Olivia, 2013) and demanding their individual portion of profit. She adds that "it's not just men; it's the women too."

I leave the NGO office thinking about how the evaluation and insights gathered from farmers and staff members problematises some of the deep assumptions made about cooperation, collaboration, and women in CSR empowerment projects. Farmers enact "everyday resistance" (Scott, 1985) against the discourses of cooperation and collaboration, so common to women's empowerment narratives. Olivia and I wonder how we will write up the findings: Can the relative success of the social and political empowerment of some women farmer leaders be called empowerment, when those very same farmers re-create the gendered power relations which keep other women poorer, in a lower status and in continued inequality in comparison to their male colleagues? Did the programme make a mistake in assuming that the farmers were willing to cooperate?

\section{RE-THINKING EMPOWERMENT IN CSR: FEMINIST FOUCAULDIAN INSIGHTS}

The vignettes introduced above present a complex picture of empowerment in Ghana, showing how people (in this case women) reject, resist, and behave in ways counterintuitive to CSR and development narratives. There are numerous economic explanations for such behaviour, relating to the amount of time women spend in unpaid care work in the home and in cocoa farming, for example, such that they do not have spare time for entrepreneurial activities. Moreover, paid work in cocoa farming can be more lucrative than craft work (given the right support). However, as noted above, empowerment is not simply an economic concept. Thus, in this section I add to, and move beyond such explanations to use Foucault's later works, and in particular his concepts of 'subjectivation' and 'freedom as an ethic of care for oneself' to explore and better understand why these individuals might have reacted to CSR women's empowerment in the ways described in the vignettes. I draw upon later Foucault because it presents alternative readings of the 'power' in empowerment, and the agency and resistance of individuals therein (Crane et al., 2008; Drebes, 2014; Knights \& Vurdubakis, 1994; Skinner, 2012). I apply feminist interpretations of Foucault's work which have been especially fruitful for understanding the construction of men and women's subject positions in society (Pullen, 2006). ${ }^{10}$ In the next two sections I first ask why women are resisting empowerment before moving to a more conjectural discussion on what it is that we mean when we seek to empower women in CSR anyway. 


\section{Why are Women Resisting Empowerment?}

As noted earlier, gendered CSR almost always chooses to focus on women (Bexell, 2012; Prügl, 2015; Tornhill, 2016a), and frequently pushes women to work in groups, collaborating for the good of other women and/or families (Switzer, 2013; Wilson, 2011). The business case for women's empowerment turns on the assumption that since women are often mothers, carers, and involved in community work, and are supposed to have better interpersonal skills than men, they will cooperate with each other for the common good (ICRW, 2016; WEF, 2013). In both my vignettes, however, we see women confounding assumptions of women as (a) communal and (b) compliant. In Vignette 2, despite a cultural barrier to women becoming leaders in the cooperative, some achieved this, to then enact that role in their own manner by "marginalising" and "resisting, dividing, and ruling" (interview with board member, 2014) other women. This is not unique to CSR, or Ghanaian contexts, but echoes studies which demonstrate the problems of essentialising women's 'nature' (e.g. Wajcman, 1998). In Vignette 1, Ama and Shirley resisted and rejected change to be anything but compliant. That the women in these stories don't act in 'ladylike' ways or in line with the discourse of 'caring, sharing' women, or that sometimes their behaviour may seem irrational or counterintuitive to outsiders does not subtract from their demonstrable agency in this situation. Understanding why this might be requires reconsidering what power is, how it is manifest, and what it means for women's empowerment in CSR in the global South.

Feminist scholars have found Foucault's middle period of writings (e.g. 1977a) useful when exploring power relations (Pullen, 2006). Foucault's focus was on language and ideas and how over time, discourses come to create 'technologies of power' which are enacted upon the subject. This power is insidious, similar to an understanding of power as something subconscious, but it is exercised by all rather than owned by one social group (Foucault, 1986), meaning it cannot be "overthrown" (Cooper, 1994: 437). Indeed, one contribution of Foucauldian thought to the study of business ethics is the role of subjects themselves in the creation and re-creation of power relations (Crane et al., 2008). Power in this reading is not necessarily negative, but can be productive:

What makes power hold good, what makes it accepted, is simply the fact that it doesn't only weigh on us a force that says no; it also transverses and produces things, it induces pleasure, forms knowledge, produces discourse (Foucault, 1977b: 120).

Thus, in this reading, the notion of empowering the 'powerless' is complicated: for example, women working in the cocoa value chain in Ghana take part in power relations and for that reason may recreate the conditions of their own inequalities, for example, by choosing to work alone rather than pool resources. Further, Ama and Shirley, and other women, were perhaps driven to act in unexpected ways because they were women in a male-dominated organisation. The discourses at play within the Ghanaian cocoa industry still place men as cocoa farmers, managers, and leaders. Ama and Shirley's fight to achieve management positions within the Ghanaian cooperative suggests high stakes, and that perhaps if they had been men, their story 
would not have played out in the same way. Yet it is clear in the vignette that Ama and Shirley are not simply conduits for patriarchy, but "multiple selves whose lives are shot through with contradictions and creative tensions" (Kondo, 1990: 224). They are individuals raised in Ghana in traditional gender roles, working with Western feminist concepts translated into their daily working lives and up against competing expectations from farmers, managers, and their own families. Ama and Shirley (re)produced gendered power relations in complex ways: I argue that they were neither powerful nor powerless, but an active part of both states.

Foucault's later work (i.e., the last two volumes of The History of Sexuality [1985, 1986]) holds further clues here. His attention shifted from technologies of power (on the individual, e.g., patriarchy) to 'technologies of the self' or subjectivation (1994) (Crane et al., 2008). These "permit individuals to effect by their own means, or with the help of others, a certain number of operations on their own bodies and soils, thoughts, conduct and way of being" (Foucault, 1994: 225) to "not only set themselves rules of conduct, but also seek to transform themselves, to change themselves in their singular being" (Foucault, 1985: 10-11). I argue that Foucault's concept of subjectivation helps us to understand why women like Ama and Shirley resist, or farmers reject traditional female roles as they "actively fashion their own identities" (McNay, 2000: 9), including gender identities, within specific cultures:

I am interested...in the way in which the subject constitutes himself in an active fashion, by the practices of the self, these practices are nevertheless not something that the individual invents by himself. They are patterns that he finds in his culture and which are proposed, suggested and imposed upon him by his culture, his society and his social group (Foucault, 1987: 11).

Thus, Ama and Shirley, who both wish to promote gender empowerment, approach this from a hybrid identity of middle-class Ghanaian business professionals, and engage in practices of the self with multiple intersectional identities: of ethnicity, gender, and class. This can intensify the 'self-policing' and conflict that subjects may experience in the subjectivation process (O'Grady, 2004). We might argue, then, that this conflict is one reason why they insisted on continuing to focus on micro-entrepreneurship, whilst rejecting women's (proven) active role in cocoa farming. Cocoa's positioning as a man's crop in Ghana means that women farmers continue to be seen as helpers rather than legitimate farmers in their own right, despite increased female land ownership. Paradoxically, Ama and Shirley's insistence on traditional crafts as empowerment modes appears to undo the gender equality progress made for women working in cocoa in Ghana. A feminist Foucauldian lens, however, suggests new ways to interpret why they behaved in this way.

These vignettes viewed through the lens of feminist Foucauldian theory confront the idea of gender as universal, structural, and essentialist (Cooper, 1994: 439) since gender is an "ongoing process, a becoming" during subjectivation (Skinner, 2012: 906; Butler, 1997). Women and men take the different subject positions drawn for them and mold, create, and re-create their own selves. As McNay (2000: 6) argues, in reimagining the role of the self in creating gendered power relations, 
it is necessary to consider that "individuals may respond in unanticipated and innovative ways which may hinder, reinforce or catalyse social change." In this way, subjectivation is intricately linked to resistance (Foucault, 1982; Knights \& Vurdubakis, 1994) and often gender resistance (Butler, 1997, 2004; Cooper, 1994; Kondo, 1990; McNay, 2000).

Resistance can be corporeal (such as Ama locking away materials) (Grosz, 1994), or discursive (arguing for craft-based empowerment only) (Butler, 1997). Some of the farming women in Vignette 2 resisted corporeally, through physical protest and refusing terms at the Fairtrade meeting, while other women leaders resisted discursively, when they turned to bullying, marginalising, and individualism. What this shows us is how gendered power relations are tightly tied to local cultural context. For example, despite a continued push from the cooperative and NGO for craft-based, economic empowerment projects, some women farmers in Vignette 1 resisted these, often because they had no time for such projects in what were already busy lives involving cocoa farming as well as significant amounts of unpaid work. When they did sign up for the projects, they often resisted taking part in group savings and loans models. This may be explained by the value of individuation within Asante culture (Clark, 1994). In these ways women farmers resisted "in complex ways to partly overturn the dominant order... but also to partly support it" (Pullen \& Simpson, 2009: 582). By desiring their autonomy, and refusing to take part in group activities, these women farmers were on one hand agentic, refusing to conform to project specifications imposed from outside their own culture. Furthermore, the small number of women leaders who marginalised other women also engaged in resistance, challenging the "development myth" of cooperative, caring women (Cornwall et al., 2008). Yet the almost universal approach to CSR and women's empowerment is to treat women as a homogenous group based on sex categories (Ahonen et al., 2014; Cornwall, 2014; Yuval-Davis, 1994). In reality, women and men create their own gender identities in a multiplicity of ways (Linstead \& Pullen, 2005), including through resistance.

Debates around gender myths and feminist fables (Cornwall et al., 2007) and the nature of women are also found in theories of relationality in business ethics (Borgerson, 2007; Painter-Morland, 2006, 2008). Relational theory argues that human development is optimised through cooperation and support (Fletcher, 1998), with women performing the necessary caring roles particularly well (Uhl-Ben, 2011). Held (1993) has argued for a form of feminine 'power to' which celebrates women's care and collaboration, a view shared in feminist ethics, ethics of care, and feminist stakeholder approaches (Burton \& Dunn, 1996; Liedtka, 1996; White, 1992; Wicks et al., 1994). Such perspectives are echoed in arguments for women-led CSR leadership (Marshall, 2011), small-business responsibility (Spence, 2014), and relational leadership (Liu, 2017; Uhl-Ben, 2011). Whilst some approaches stress that socialisation, positioned as the cause of difference in men's and women's behaviour, allows for shifts in gender stereotypes (e.g. Uhl-Ben, 2011; Werhane \& PainterMorland, 2011), critics have expressed concern over the essentialism or reductionism that a focus on difference has created (Derry, 1996). Socialisation is often framed as structural and rigid, especially when it comes to static gender roles (McNay, 2000). 
This narrative of gender difference has eclipsed the nuance of feminist ethics (Borgerson, 2007), like the gender and development rhetoric (Cornwall, 2007). This narrowing of ideas around gender and feminism can be damaging to gender equality since it reifies differences between men and women in ways that serve to replicate existing power relations (Grimshaw, 1993; McNay, 2000). However, it is not my intention to enter into a debate about feminist ethics or an ethic of care in this article, but rather to point out that a similar oversimplification of the social construction of gender roles (Borgerson, 2007; Uhl-Ben, 2011) has occurred in the CSR women's empowerment discourse.

My vignettes, viewed through a Foucauldian understanding of power, illustrate how women are individuals, and act as such, but within a system of power relations which "constrains and enables" actors who push at the boundaries of possibility (Hayward, 2000: 12) (Foucault, 1982). As active constituents of their own worlds, the women leaders marginalising other women, or women farmers rejecting programmes, are seizing empowerment opportunities-just not in ways CSR managers may wish for (Cooper, 1994; Pullen, 2006; Sawicki, 1991). Seeing power relations in this way is important for exploring empowerment because it means that women, in particular, are moved out of the category of 'victim' and afforded agency, meaning that "despite large scale gender inequalities, women are not just passive dupes of patriarchal structures of domination" (McNay, 1992: 82). It means that women are recognised as individuals, and not simply symbolic of relational skills, collaboration, or care.

\section{How is Women's Empowerment in CSR 'Empowering'?}

A feminist Foucauldian lens on CSR women's empowerment programmes highlights some of the paradoxes at play within this recent management phenomenon. Foucault elucidates how women (and men) 'self-make' themselves, often through resistance. This helps us to better understand why it is that women in the vignettes acted in ways counterintuitive to Western, CSR-based notions of development. Are these women who reject empowerment projects, or assumed gender roles, empowered when they do this? Or do we need to rethink what the term means? In this section I use Foucault's later work $(1985,1986,1987)$ to ask: What is it that women's empowerment in CSR contexts is actually aiming to do? What is it that women are being empowered from or to?

Since power is understood to be an ongoing, relational element of human subjectivation, so too can freedom be perceived as an ongoing process inextricably linked to our everyday existence (Amigot \& Pujal, 2009; Crane et al., 2008; Foucault, 1987). This is very different from a liberal approach to freedom, which we are more familiar with, where human beings require 'freeing from' one state of being in preference for another (Berlin, 1969). In contrast, Foucault (1987) regards freedom as "the ability to participate actively and purposefully in power relations" (Crane et al., 2008: 304). Therefore, "Foucault's conception of personal freedom...is never an absolute state, or an end point in a liberation struggle, but rather a defining characteristic of what it is to be human" (Crane et al., 2008: 303). Women's empowerment is thus more complicated than freeing women to acquire wealth, or practice care, or freeing them 
from patriarchal control. Instead, as Foucault $(1985,1986,1987)$ theorises in his exploration of sexuality in Greek antiquity, freedom is related to 'an ethics of care for the self.' This is 'to give oneself the rules of law, the techniques of management, and also the ethics, the ethos, the practice of the self, that will allow these games of power to be played with the minimum of domination" (Foucault, 1987: 12). Freedom is rooted within the individual's search for an internal ethics, in a constant interplay of power relations within the self (Foucault, 1987). "In short, one must abandon the political calculus of domination and liberation" (Rose, 1999: 95). To paraphrase Rose (1999: 65), a Foucauldian approach to CSR and women's empowerment questions how women and men in value chains are "defining and acting towards themselves in terms of a certain notion of freedom." This then raises the question as to what women can acquire for themselves-knowledge, practices of the self, and ethics - to be 'free.'

My vignettes illustrate the subjectivation process (which we can consider as an internal process) and the often difficult (external) contexts in which women and men co-construct their own freedoms, in this case in the context of a gendered cocoa industry, material poverty, and a well-meaning, yet ineffective, CSR intervention (Amigot \& Pujal, 2009; Hirschmann, 2002; O'Grady, 2004; Pullen, 2006). Even within constrained contexts such as these, from a Foucauldian perspective, women managers and farmers are 'free,' since they take an ethic of care of themselves, symbolised by their resistance and engagement in power relations within the empowerment programme itself (Crane et al., 2008). This freedom, however, does not reflect how freedom and empowerment are usually understood, since there may be very few immediate material benefits or changes arising from such a process (Hirschmann, 2002).

Thus, a feminist Foucauldian approach moves away from existing notions of feminist and care ethics which often position women as instrumental to other's freedom, e.g., as more ethical managers (e.g. Liedtka, 1996; White, 1992), or which perceive freedom as lying in individuals' capacity to exercise care for others (e.g., Held, 1993). This is because Foucault theorises that freedom lies in the capacity to choose an ethic of care for oneself. Rather than care being understood as behaviour directed externally, to others' needs, "care is better treated as a disposition or attitude that may be incorporated into one's own freely chosen rules of conduct, where respect for one's own and others' freedom is the fundamental principle" (Syballa, 2001: 79). This important distinction does not undermine the importance of caring for others, which also remains part of Foucault's ethos (O'Grady, 2004; Syballa, 2001), but it legitimises thinking, talking, and working with women as individuals, and not as a homogenous mechanism for societal, business, or national growth. Situating freedom within an ethic of care for oneself signals returning to women as individuals, but not atomised individuals, since they are always interacting with, and in relation to, others. Furthermore, whilst an ethic of care for oneself does focus on individual subjects, it does not remove them from historic, societal, economic, or cultural limits (Syballa, 2001). In this way, we better understand gender inequality as a multi-level phenomenon: corresponding to and interlinked between individuals, groups, and society, and empowerment related to an individual recognising the capacity 
to choose different pathways, even when these pathways might seem irrational to onlookers unaware of the complexities of others' lives.

The vignettes, however, demonstrate how freedom with regard to CSR women's empowerment has been sold as individual women becoming entrepreneurs (Cornwall, 2007; Roberts, 2015). This single example is symbolic of a much larger shift towards the "empowered, self-made (wo)man" narrative in management, development, and CSR (Batliwala, 2007; Hardy \& Leiba-O'Sullivan, 1998; Tornhill, 2016b). This narrative encapsulates technologies of consumption illustrated within women's base of the pyramid schemes (e.g. in Unilever's Project Shakti; Prügl, 2015) and technologies of therapeutics illustrated in 'self-actualisation' training (e.g. in Coca-Cola's 5by20 initiative; Tornhill, 2016b), which conceptualise "freedom as autonomy" (Rose, 1999). This view champions freedom as lying solely in the capacity to please oneself (Rose, 1999). This is arguably at the heart of CSR and women's empowerment, given that it focuses on empowerment as a lone endeavour, unrelated to the structural elements of gender inequality, and targeted almost exclusively on personal wealth accumulation (Roberts, 2015; Switzer, 2013). In Vignette 2, women's group work was ultimately addressed at women as individual wealth-generators, a far-cry from the original conceptualisation of women's groups for consciousness-raising purposes (Batliwala, 2007). It becomes clear that such atomistic framing of societal problems such as gender inequality, and the individualistic 'solutions' offered through CSR women's empowerment programmes, are inadequate on both moral (Rose, 1999) and practical grounds (Batliwala, 2007).

Finally, despite the subjectivation and resistance I have shown occurring at the intersections of women's empowerment programmes and CSR in the global South, the neoliberal framing of freedom (Amigot \& Pujal, 2009) remains one of corporations empowering women on their behalf. This falls into Foucault's concern with "the indignity of speaking for others" (Deleuze, 1977 in Foucault \& Deleuze, 1977: 209) when power's diffuse nature requires marginalised women to lead their struggle with their own forms of action. Yet once again, we must be aware that individuals may respond with passivity within power relations (Foucault \& Deleuze, 1977: 216). Women may respond in ways that are not in line with the rational, neoliberal discourse of freedom, or empowerment. Since human subjects are involved in the creation of their own freedoms, they have both the potential to provoke or limit their own version of self-mastery. I conclude by exploring what these paradoxical positions mean for practice and for future theorising on gender, CSR, and empowerment.

\section{CONCLUDING REMARKS}

Programmes to enable the empowerment of women have become a feature of many CSR policies. Yet there are several myths associated with the term 'empowerment' which are tied to misunderstandings around the concepts of 'power' and 'gender.' For many, women's empowerment translates to 'empowering women.' This linguistic slip is crucial, for it positions the main agents of empowerment as outside of the women themselves: be they NGOs, governments, or companies; and depicts women as objects onto which empowerment is 'done.' This formulation chimes with the criticisms levied 
at other CSR development initiatives (Drebes, 2014; Khan \& Lund-Thomsen, 2011) which tend to cast those in the global South as 'voiceless, powerless victims' or 'beneficiaries.' Banerjee (2010: 272) points out that much CSR scholarship neglects to look "at the demand side of the CSR equation" and the choices, agency, and resistance of respective workers and communities.

I therefore contribute to theories on CSR and development by showing how men and women can resist CSR, generally, and women's empowerment programmes, in particular, in unexpected ways and with seemingly paradoxical responses. I have argued that a Foucauldian conceptualisation of power relations as pervasive and relational: not 'held' by anyone or enacted 'against' anything, but existing in relationships between human subjects (Foucault, 1982,1986) is helpful. Specifically, the feminist Foucauldian attention to subjectivation and freedom (Butler, 1997; McNay, 1992, 2000; Sawicki, 1991) offers nuanced insights into the complex power relations at play in contexts of CSR women's empowerment. Chiefly, since inequalities are tied up in power relations that all individuals are involved in producing, individuals can 'craft themselves' (Kondo, 1990), challenging and resisting gender roles in numerous ways, some of which may appears puzzling to outsiders.

The article also highlights two important aspects of the CSR and women's economic empowerment myth: first, that entrepreneurship discourses are rarely just about gender, but include ethnicity, class, and nationhood which entwine in a mesh of hybrid identities (Calás \& Smircich, 2006). Therefore, the story is more complicated than the global North holding power over the global South, but demonstrates the complex playing out of post-colonial history within CSR (Drebes, 2014), where "new subjectivities of transnationalism" proliferate in gendered ways (Calás \& Smircich, 2006: 321). Second, it demonstrates how CSR women's empowerment projects, if they continue to pursue narrow objectives of entrepreneurship, can further marginalise women from mainstream value chains (e.g. by pushing women into craft-based, rather than cocoa-based, work). This raises questions as to what extent CSR for women's empowerment is desirable, when managers (in all locations) ignore local contexts and thus recreate gendered and racialised 'difference.' Thus, future research and theory building might wish to adopt an intersectional approach to CSR and business ethics, in order to pay better attention to individuals' lives along the intersections of their experience: gender, ethnicity, disability, class, and other categories (Crenshaw, 1991; Holvino, 2010).

Further, an exploration of what 'freedom' means in relation to empowerment highlights that a corporate adoption of the term is far from the Foucauldian concept of freedom that exists when individuals are able to engage in an ethic of care with themselves (Foucault, 1985, 1986, 1987). Like recent criticisms of diversity initiatives (Ahonen et al., 2014) and rule-based CSR codes of conduct (Crane et al., 2008), empowerment programmes which utilise universal means and goals do not allow for the processual, personal nature of freedom, or how those who CSR aims to help are both provider and provided for, subject and object. Since the workers at the receiving end of programmes will likely respond to and produce their own forms of power, gender, and freedom, CSR for women's empowerment would require subverting assumptions about who and 
what 'women' are (Cornwall, 2007). The continual recasting of women as a synonym for gender, the conflation of sex and gender, and the 'development myth and feminist fable' of women saving the world in sisterhood are legion (Cornwall et al., 2007; Koffman \& Gill, 2013; Switzer, 2013). Echoing early concerns with the essentialism contained within misunderstandings of 'feminine' and feminist ethics (Derry, 1996), women in the global South are continuously positioned as saviours of others because of their sex. Indeed, there is no escape from the confines of this fixed gender identity because the identity itself has been co-opted as a strategy for empowerment. This means a concern over inequalities has moved away from an understanding of gender as an embodied, discursive, social construct and back towards a fixed identity. Future theorising on the role of women and men in CSR should once more scrutinise how these categories are constructed and construed within research. CSR in practice, and as a theory, risks becoming useless if the core problems it wishes to improve, such as gender inequality, are ill-understood.

This is not to dissuade a corporate social responsibility focus on gender inequalities. Business recognition of the importance of gender inequality and marginalised female stakeholders in their organisations and wider value chains is a step in the right direction. My concern is with the narrow framing of CSR as a vehicle for gender equality through women's empowerment programmes. Echoing concerns of others (Roberts, 2015; Tornhill, 2016b; Wilson, 2011), I would ask whether businesses enacting CSR can support empowerment in its fullest sense, when that requires stepping back and allowing men and women to enact their own forms of freedom. Rose (1999: 97) calls for "ways of organizing our concern for others that did not seek to set them free-relations of obligation, of commitment, perhaps evoking an older sense of care." In relation to CSR programmes, this may mean moving beyond an enterprise-based idea of empowerment that relies upon women and men becoming better consumers or entrepreneurs to be 'empowered' or 'developed.' It would mean framing women's empowerment less as a business, or national, opportunity and more as an obligation for business and governments. The current focus on empowering women through CSR has eclipsed a wider, and perhaps more crucial, conversation on mainstreaming gender equality throughout all dimensions of a business and into market economies. As in the Ghanaian case here, a concerted effort to challenge the assumptions around cocoa as a male crop, by targeting training and resources at women farmers for example, would be one means of gendering the business' CSR. Further, businesses could engage in championing reproductive autonomy, safety from violence, freedom of association, and childcare provision through their own operations and through partnership or lobbying. To promote gender equality, all these actions would be good places for businesses to start, whilst being cautious in not 'speaking for others' (Foucault \& Deleuze, 1977) and inadvertently recreating inequalities as shown here.

A practical solution to some of these problems in CSR and women's empowerment may be closer attention to what women [and men] really want, to borrow a cliché. First, the inclusion as men within gender equality efforts is key, since they remain influential actors within organisations, industries, and households (Cornwall, 2014). Men and masculinities need to be brought into conversations around equality and 
empowerment, not just in the field but also as potential 'elite allies' within CSR management (Grosser, McCarthy, \& Kilgour, 2016). A key benefit of taking a feminist Foucauldian approach has been that it moves away from binary understandings of gender (i.e. a focus on women only) to exploring how human individuals take part in power relations, in relation to each other and the consequences this has for certain groups of people (Pullen, 2006). Moving beyond a woman-only approach to empowerment and incorporating men as also having responsibility for social change would be a welcome development.

Second, we continue to know very little about people's hopes, desires, and experiences within CSR initiatives (Ansari et al., 2012; Banerjee, 2010) and issues of gender and power are known to effect stakeholder engagement efforts (Grosser \& Moon, 2005; Grosser, 2009) as well as impact assessments (Barrientos et al., 2003). Participatory methods may offer innovative ways in which to get closer to individuals' experiences, meaning making, and intentions, as the onus lies on in-situ understandings, processes, and the participation of women and men who are ostensibly at the heart of CSR programmes (McCarthy \& Muthuri, 2016). Happily, the women's empowerment programme in this Ghanaian case has now incorporated a more reflexive approach to gender inequality, beginning literacy classes open to both sexes, and considering how men might be brought into projects (McCarthy \& Muthuri, 2016).

Ultimately, since power and freedom are deeply connected to the self, the potential for change, through CSR, may lie in starting from the position that empowerment and its processes come from within ourselves as individuals and "how we relate to ourselves and others" (Crane et al., 2008: 315). 'Freeing' women from poverty, or inequality, through CSR empowerment programmes may become problematic when we make assumptions about what women need to be freed from, or how this should be done. Facilitating reflection, space for discussion, and women and men workers' own desires, should be a goal for research and practice.

\section{ACKNOWLEDGEMENTS}

Thanks to Jean-Pascal Gond, Ed Freeman, Charlotte Karam, Jeremy Moon, Judy Muthuri, and Laura Spence, who have helped develop and refine previous iterations of this article. The author would like to acknowledge the support of the Velux Chair for Corporate Sustainability at Copenhagen Business School during the writing of this article. Thank you to the handling editor, Kate Grosser, and the four anonymous reviewers for detailed and developmental comments and suggestions. Finally, thanks to the women involved in the study for their time and insight.

\section{NOTES}

1. According to one study in 2016 over 31 million USD was invested in 31 corporate women's empowerment programmes (ICRW, 2016).

2. In this article, I mainly explore women's resistance and interaction with women's empowerment programmes, since so much of the focus within these CSR interventions is on women per se. However, men are also key actors within this story, as they engage with, or affect, the outcomes of empowerment programmes as well. The particular role of men within women's CSR empowerment projects is a ripe area for future research. 
3. Girl Effect is a campaign and development programme, created and launched at Davos in 2009 by The Nike Foundation. Partners include the United Nations. In 2015 it became an NGO in its own right (www.girleffect.org). Through awareness raising and training it seeks to empower girls in developing countries, "as co-creators of new solutions" to global poverty.

4. In 2010 Coca-Cola pledged to economically empower 5 million women in their value chain by 2020. Working with partners such as Care (an NGO), the 5 by20 initiative seeks to unleash the entrepreneurial spirit of women through skills and microfinance training. http://www.coca-colacompany. com/5by 20 .

5. The cooperative was founded to collectivise smallholder cocoa farmers to bring them further up the value chain. Cocoa is grown on small plots of land by farmers, who then decide who to sell their produce to. Members of the cooperative receive a Fairtrade price for their cocoa, as well as benefits such as a free cutlass and the benefit of local social initiatives such as health clinics and training.

6. Participant-led drawing was used to address sensitive and culturally contextual concepts, such as 'gender' and 'inequality,' beyond the verbal. This was a means of trying to find another way of 'hearing' workers' 'voice' and addressing some of the power imbalances between researcher and researched in global South settings (McCarthy \& Muthuri, 2016).

7. Crops become ascribed with gendered social norms about who should grow and sell them. Cocoa, as a cash crop, is seen as being appropriate work for male farmers, but less for women. Crops grown for domestic subsistence are labelled as 'women's crops' (Doss, 2002).

8. Ghana has over 100 ethnic groups. The Asante (sometimes written as Ashanti) are found mainly in central Ghana.

9. Land inheritance law and customs in Ghana vary by region, and are complex. For example, elder women in the Asante culture decide alongside village chiefs to whom land will be passed, but the practice is that land usually goes to sisters' sons, meaning land ownership in general remains male-dominated (Barrientos \& Bobie, 2016; Quisumbing et al., 2004).

10. However, it is important to acknowledge that feminist interpretations of Foucault's work have been controversial. Some have picked up on his masculinist tendencies in language (Grimshaw, 1993; McNay, 1992), and perhaps more troublingly, what has been termed his 'sexist' genealogy of sex and ethics, which focuses on free men in Greek antiquity, and thus erases the embodied experiences of those enslaved and/or female (Grimshaw, 1993).

\section{REFERENCES}

Acker, J. 1990. Hierarchies, jobs, bodies: A theory of gendered organizations. Gender \& Society, 4(2): 139-158.

Adanhounme, A. B. 2011. Corporate social responsibility in postcolonial Africa: Another civilizing mission? Journal of Change Management, 11(1): 91-110.

Ahonen, P., Tienari, J., Meriläinen, S., \& Pullen, A. 2014. Hidden contexts and invisible power relations: A Foucauldian reading of diversity research. Human Relations, 67(3): 263-286.

Amigot, P., \& Pujal, M. 2009. On power, freedom, and gender: A fruitful tension between Foucault and feminism. Theory \& Psychology, 19(5): 646-669.

Ansari, S., Munir, K., \& Gregg, T. 2012. Impact at the 'Bottom of the pyramid': The role of social capital in capability development and community empowerment. Journal of Management Studies, 49(4): 813-842.

Baden, S., Green, C., Otoo-Oyortey, N., \& Peasgood, T. 1994. Background paper on gender issues in Ghana. BRIDGE development-gender report, No. 19. Brighton, UK: Institute of Development Studies.

Banerjee, S. B. 2010. Governing the global corporation: A critical perspective. Business Ethics Quarterly, 2(2): 265-274.

Barrientos, S. 2013. Gender production networks: Cocoa-sustaining cocoa-chocolate sourcing from Ghana and India. Brooks World Poverty Institute working paper, No. 186. Manchester, UK: University of Manchester. 
Barrientos, S., \& Bobie, A. O. 2016. Promoting gender equality in the cocoa-chocolate value chain: Opportunities and challenges in Ghana. GDI Working Paper 2016-006. Manchester, UK: University of Manchester.

Barrientos, S., Dolan, C., \& Tallontire, A. 2003. A gendered value chain approach to codes of conduct in African horticulture. World Development, 31(9): 511-1526.

Batliwala, S. 2007. Taking the power out of empowerment: An experiential account. Development in Practice, 17(4/5): 557-565.

Berlin, I. 1969. Two concepts of liberty. In I. Berlin, Four essays on liberty. Oxford: Oxford University Press.

Bexell, M. 2012. Global governance, gains and gender: UN-business partnerships for women's empowerment. International Feminist Journal of Politics, 14(3): 389-407.

Borgerson, J. L. 2007. On the harmony of feminist ethics and business ethics. Business and Society Review, 112(4): 477-509.

Bowring, M. A. 2004. Resistance is not futile: Liberating Captain Janeway from the masculine-feminine dualism of leadership. Gender, Work \& Organization, 11(4): 381-405.

Burton, B., \& Dunn, C. 1996. Feminist ethics as moral grounding for stakeholder theory. Business Ethics Quarterly, 6(2): 133-148.

Butler, J. 1997. Excitable speech: A politics of the performative. London \& New York: Routledge.

Butler, J. 2004. Undoing gender. London \& New York: Routledge.

Calás, M. B., \& Smircich, L. 2006. From the 'Woman's point of view' ten years later: Towards a feminist organization studies. In S. R. Clegg, C. Hardy, T. B. Lawrence, \& W. R. Nord (Eds.), The SAGE handbook of organization studies: 284-346. Thousand Oaks, CA: SAGE.

Chaudhry, L. N. 2009. Forays into the mist: Violences, voices, vignettes. In A. Y. Jackson \& L. A. Mazzei (Eds.), Voice in qualitative inquiry: Challenging conventional, interpretive and critical conceptions in qualitative research: 137-164. London \& New York: Routledge.

Clark, G. 1994. Onions are my husband: Survival and accumulation by West African market women. Chicago: University of Chicago Press.

Coca-Cola Company. 2012. Sustainability Report 2011/2012.

Coleman, I. 2010. The global glass ceiling. Foreign Affairs, 89(3): 13-20.

Coles, C., \& Mitchell, J. 2011. Gender and agricultural value chains and practice and their policy implications. Rome: Food and Agriculture Organization.

Cooper, D. 1994. Productive, relational and everywhere? Conceptualising power and resistance within Foucauldian feminism. Sociology, 28(2): 435-454.

Cornwall, A. 2007. Myths to live by? Female solidarity and female autonomy reconsidered. Development and Change, 38(1): 149-168.

. 2014. Women's empowerment: What works and why? WIDER Working Paper No. 2014/104. Helsinki: World Institute for Development Economics Research.

Cornwall, A., \& Anyidoho, N. A. 2010. Introduction: Women's empowerment: Contentions and contestations. Development, 53(2): 144-149.

Cornwall, A., Gideon, J., \& Wilson, K. 2008. Introduction: Reclaiming feminism: Gender and neoliberalism. IDS Bulletin, 39(6): 1-9.

Cornwall, A., Harrison, E., \& Whitehead, A. 2007. Gender myths and feminist fables: The struggle for interpretive power in gender and development. Development and Change, 38(1): 1-20. 
Crane, A., Knights, D., \& Starkey, K. 2008. The conditions of our freedom: Foucault, organization and ethics. Business Ethics Quarterly, 18(3): 299-320.

Crenshaw, K. 1991. Mapping the margins: Intersectionality, identity politics, and violence against women of color. Stanford Law Review, 1241-1299.

Derry, R. 1996. Toward a feminist firm. Business Ethics Quarterly, 6(1): 101-109.

Dobson, J., \& White, J. 1995. Toward the feminine firm: An extension to Thomas White. Business Ethics Quarterly, 5(03): 463-478.

Doss, C. R. 2002. Men's crops? Women's crops? The gender patterns of cropping in Ghana. World Development, 30(11): 1987-2000.

Drebes, M. 2014. Including the 'Other': Power and postcolonialism as underrepresented perspectives in the discourse on corporate social responsibility. Critical Sociology, 42(1): 105-121.

Duflo, E. 2012. Women empowerment and economic development. Journal of Economic Literature, 50(4): 1051-1079.

Duncan, B. A. 2010. Cocoa, marriage, labour and land in Ghana: Some matrilineal and patrilineal perspectives. International African Institute, 80(2): 301-321.

Elson, D., \& Pearson, R. 1981. 'Nimble fingers make cheap workers': An analysis of women's employment in third world export manufacturing. Feminist Review, 7(1): 87-107.

Fletcher, J. K. 1998. Relational practice: A feminist reconstruction of work. Journal of Management Inquiry, 7(2): 163.

Foucault, M. 1977a. Discipline and punish. Middlesex, UK: Penguin.

- 1977b. Truth and power. In J. D. Faubion (Ed.), Power. Essential works of Foucault 1954-1984, Volume 3: 111-133. London: Penguin.

- 1978. The history of sexuality volume 1: The will to knowledge. Harmondsworth, UK: Penguin.

1980. Power/knowledge: Selected interviews and other writings 1972-7. Brighton, UK: Harvester Press.

. 1982. The subject and power. Critical Inquiry, 8(4): 777-795.

. 1985. The history of sexuality volume 2: The use of pleasure. Harmondsworth, UK: Penguin.

1986. The history of sexuality volume 3: The care of the self. New York: Vintage.

1987. The ethics of the concern of the self as a practice of freedom. An interview translated by J. D. Gauthier. In J. Bernauer \& D. Rasmussen (Eds.), The final Foucault: 1-20. London \& Cambridge, Mass: MIT Press.

1994. Technologies of the self. In P. Rabinow (Ed.), Ethics: Subjectivity and truth.

(Essential works of Michel Foucault, 1954-1984, volume 1): 223-254. London: Penguin.

Foucault, M., \& Deleuze, G. 1977. Intellectuals and power. In D. Bouchard (Ed.), Language, counter-memory, practice: 207-217. Ithaca: Cornell University Press.

Freeman, R. E., \& Liedtka, J. 1997. Stakeholder capitalism and the value chain. European Management Journal, 15(3): 286-296.

Freire, P. 1970. Pedagogy of the oppressed. New York: Herder and Herder.

Gond, J-P., \& Moon, J. 2011. Corporate social responsibility in retrospect and prospect: Exploring the life-cycle of an essentially contested concept. In J-P. Gond \& J. Moon (Eds.), Corporate social responsibility: A reader (vol. 1): 1-28. New York: Routledge.

Grimshaw, J. 1993. Practices of freedom. In C. Ramazanoglu (Ed.), Up against Foucault: Explorations of some tensions between Foucault and feminism: 51-72. London \& New York: Routledge. 
Grosser, K., \& Moon, J., 2005. The role of corporate social responsibility in gender mainstreaming. International Feminist Journal of Politics, 7(4): 532-554.

Grosser, K. 2009. Corporate social responsibility and gender equality: Women as stakeholders and the European Union sustainability strategy. Business Ethics: A European Review, 18(3): 290-307.

Grosser, K., McCarthy, L., \& Kilgour, M. A. (Eds.). 2016. Gender equality and responsible business: Expanding CSR horizons. Saltaire, UK: Greenleaf.

Grosz, E. 1994. Volatile bodies: Toward a corporeal feminism. Bloomington: Indiana University Press.

Hale, A., \& Opondo, M. 2005. Humanising the cut flower chain: Confronting the realities of flower production for workers in Kenya. Antipode, 37(2): 301-323.

Hardy, C., \& Leiba-O'Sullivan, S. 1998. The power behind empowerment: Implications for research and practice. Human Relations, 51(4): 451-483.

Hayward, C. R. 2000. De-Facing power. Cambridge: Cambridge University Press.

Held, V. 1993. Feminist morality: Transforming culture, society, and politics. Chicago, IL: Chicago University Press.

Hirschmann, N. J. 2002. The subject of liberty: Toward a feminist theory of freedom. Princeton \& Oxford: Princeton University Press.

Holvino, E. 2010. Intersections: The simultaneity of race, gender and class in organization studies. Gender, Work \& Organization, 17(3): 248-277.

Hudon, M., \& Sandberg, J. 2013. The ethical crisis in microfinance: Issues, findings, and implications. Business Ethics Quarterly, 23(4): 561-589.

Hughes, R. 1998. Considering the vignette technique and its application to a study of druginjecting and HIV risk and safer behaviour. Sociology of Health and Illness, 20(3): 381-400.

Humphreys, M. 2005. Getting personal: Reflexivity and autoethnographic vignettes. Qualitative Inquiry, 11(6): 840-860.

ICRW. 2016. The business case for women's economic empowerment: An integrated approach. Washington, D.C.: ICRW.

Kabeer, N. 1999. Resources, agency, achievements: Reflections on the measurement of women's empowerment. Development and Change, 30(3): 435-464.

Kabeer, N., \& Mahmud, S. 2004. Globalization, gender and poverty: Bangladeshi women workers in export and local markets. Journal of International Development, 16(1): 93-109.

Karam, C. M., \& Jamali, D. 2013. Gendering CSR in the Arab Middle East: An institutional perspective. Business Ethics Quarterly, 23(1): 31-68.

Kelan, E. K. 2010. Gender logic and (un)doing gender at work. Gender, Work \& Organization, 17(2): 174-194.

Khan, F. R., \& Lund-Thomsen, P. 2011. CSR as imperialism: Towards a phenomenological approach to CSR in the developing world. Journal of Change Management, 11(1): 73-90.

Knights, D., \& Vurdubakis, T. 1994. Foucault, power, resistance and all that. In J. M. Jermier, D. Knights, \& W. R. Nord (Eds.), Resistance and power in organizations: 167-198. London \& New York: Routledge.

Koffman, O., \& Gill, R. 2013. 'The revolution will be led by a 12-year-old-girl': Girl power and global biopolitics. Feminist Review, 105: 83-102.

Kondo, D. K. 1990. Crafting selves: Power, gender, and discourses of identity in a Japanese workplace. Chicago: Chicago University Press. 
Liedtka, J. M. 1996. Feminist morality and competitive reality: A role for an ethic of care? Business Ethics Quarterly, 6(2): 179-200.

Linstead, A., \& Brewis, J. 2004. Editorial: Beyond boundaries: Towards fluidity in theorizing and practice. Gender, Work \& Organization, 11(4): 355-362.

Linstead, S., \& Pullen, A. 2005. Fluid identities and un-gendering the future. In A. Pullen \& S. Linstead (Eds.), Organization and identity: 242-269. London: Routledge.

Liu, H. 2017. Reimagining ethical leadership as a relational, contextual and political practice. Leadership, 13: 343-367.

Lukes, S. 1974/2005. Power: A radical view ( $2^{\text {nd }}$ ed.). Basingstoke, UK: Palgrave Macmillan. Marshall, J. 2011. En-gendering notions of leadership for sustainability. Gender, Work \& Organization, 18(3): 263-281.

Mayoux, L. 1999. Questioning virtuous spirals: Microfinance and women's empowerment in Africa. Journal of International Development, 11(1): 957-984.

McCarthy, L., \& Muthuri, J. N. 2016. Engaging fringe stakeholders in business and society research: Applying visual participatory research methods. Business \& Society. DOI: 10.1177/0007650316675610.

McNay, L. 1992. Foucault and feminism: Power, gender, and the self. Boston: Northeastern University Press.

2000. Gender and agency: reconfiguring the subject in feminist and social theory. Cambridge, UK: Polity Press.

Maertens, M., \& Swinnen, J. 2010. Are African high-value horticulture supply chains bearers of gender inequality? Rome: The World Bank.

Mena, S., de Leede, M., Baumann, D., Black, N., Lindeman, S., \& McShane, L. 2010. Advancing the business and human rights agenda: Dialogue, empowerment, and constructive engagement. Journal of Business Ethics, 93(1): 161-188.

Mercer. 2016. When women thrive: Global report 2016. New York: Mercer.

O'Grady, H. 2004. An ethics of the self. In D. Taylor \& K. Vingtnes (Eds.), Feminism and the final Foucault: 91-117. Champaign, IL: Illinois University Press.

Oxfam. 2012. Gender equality: It's your business. Oxford: Oxfam International.

Painter-Morland, M. 2006. Redefining accountability as relational responsiveness. Journal of Business Ethics, 66(1): 89-98.

2008. Systemic leadership and the emergence of ethical responsiveness. Journal of Business Ethics, 82(2): 509-524.

Pearson, R. 2007. Beyond women workers: Gendering CSR. Third World Quarterly, 28(4): 731-749.

Pellegrino, G., D'Amato, S., \& Weisberg, A. 2011. The Gender dividend: Making the business case for investing in women. New York: Deloitte.

Prügl, E. 2015. Neoliberalising feminism. New Political Economy, 20(4): 614-631.

Pullen, A. 2006. Gendering the research self: Social practice and corporeal multiplicity in the writing of organizational research. Gender, Work \& Organization, 13(3): 277-298.

Pullen, A., \& Knights, D. 2007. Editorial: Undoing gender: Organizing and disorganizing performance. Gender, Work \& Organization, 14(6): 505-511.

Pullen, A., \& Simpson, R. 2009. Managing difference in feminized work: Men, otherness and social practice. Human Relations, 62(4): 561-587.

Quisumbing, A. R., Payongayong, E. M., \& Otsuka, K. 2004. Are wealth transfers biased against girls? Gender difference in land inheritance and schooling investment in Ghana's Western region. Washington, D.C.: The World Bank. 
Ramazanoglu, C., \& Holland, J. 2002. Feminist methodology: Challenges and choices. London: SAGE.

Reiman, J. 1987. Exploitation, force, and the moral assessment of capitalism: Thoughts on Roemer and Cohen. Philosophy \& Public Affairs, 16(1): 3-41.

Roberts, A. 2015. The Political Economy of "Transnational business feminism." International Feminist Journal of Politics, 17(2): 209-231.

Rohatynskyj, M. 2011. Development discourse and selling soap in Madhya Pradesh, India. Human Organization, 70(1): 63-73.

Rose, N. 1999. Powers of freedom: Reframing political thought. New York: Cambridge University Press.

Rowlands, J. 1995. Empowerment examined. Development in Practice, 5(2): 101-107.

Sawicki, J. 1991. Disciplining Foucault: Feminism, power and the body. London \& New York: Routledge.

Scott, J. C. 1985. Weapons of the weak: Everyday forms of peasant resistance. New Haven, CT: Yale University Press.

Skinner, D. 2012. Foucault, subjectivity and ethics: towards a self-forming subject. Organization, 20(6): 904-923.

Spence, L. J. 2014. Small business social responsibility: Expanding core CSR theory. Business \& Society, 55(1): 23-55.

2016. The obfuscation of gender-awareness and feminism in CSR research and the academic community: An essay. In K. Grosser, L. McCarthy, \& M. A. Kilgour (Eds.), Gender equality and responsible business: Expanding CSR horizons: 16-30. Saltaire, UK: Greenleaf.

Summerson-Carr, E. 2003. Rethinking empowerment theory using a feminist lens: The importance of process. Affilia, 18(1): 8-20.

Switzer, H. 2013. (Post)feminist development fables: The Girl Effect and the production of sexual subjects. Feminist Theory, 14(3): 345-360.

Sybylla, R. 2001. Hearing whose voice? The ethics of care and the practices of liberty: A critique. Economy and Society, 30(1): 66-84.

Syed, J., \& Van Buren, H. 2014. Global business norms and Islamic views of women's employment. Business Ethics Quarterly, 24(2): 251-276.

Tornhill, S. 2016a. The wins of corporate gender equality politics: Coca-Cola and female microentrepreneurship in South Africa. In K. Grosser, L. McCarthy, \& M. A. Kilgour (Eds.), Gender equality and responsible business: Expanding CSR horizons: 185-202. Saltaire, UK: Greenleaf.

. 2016b. "A bulletin board of dreams": Corporate empowerment promotion and feminist implications. International Feminist Journal of Politics, 18(4): $528-543$.

Uhl-Ben, M. 2011. Relational leadership and gender: From hierarchy to relationality. In P. H. Werhane \& M. Painter-Morland (Eds.), Leadership, gender, and organization: 75-108. Heidelberg, London, New York: Springer Dordrecht.

VanMaanen, J. 1988. Tales of the field. Chicago: Chicago University Press.

Wajcman, J. 1998. Managing like a man: Women and men in corporate management. Cambridge, UK: Polity Press.

Waring, M. 1988. If women counted: A new feminist economics. London: Macmillan.

Werhane, P. H., \& Painter-Morland, M. 2011. Editors' introduction. In P. H. Werhane \& M. Painter-Morland (Eds.), Leadership, gender, and organization: 65-66. Heidelberg, London, New York: Springer Dordrecht. 
White, T. 1992. Business, ethics, and Carol Gilligan's “two voices.” Business Ethics Quarterly, 2(1): 51-61.

Wicks, A. C. 1996. Reflections on the practical relevance of feminist thought to business. Business Ethics Quarterly, 6(4): 523-531.

Wicks, A. C., Gilbert Jr., D. R., \& Freeman, R. E. 1994. A feminist reinterpretation of the stakeholder concept. Business Ethics Quarterly, 4(4): 475-497.

Wilson, K. 2011. 'Race,' gender and neoliberalism: changing visual representations in development. Third World Quarterly, 32(2): 315-331.

World Bank. 2011. World development report 2012: Gender equality and development, Washington, D.C.: The World Bank.

World Economic Forum (WEF). 2013. Five challenges, one solution: Women. Global agenda council on women's empowerment 2011 - 2012. Geneva: WEF.

Yeager, R., \& Goldenberg, E. 2012. HERproject women's health program delivers real business returns. Global Business and Organizational Excellence, (January/February): 24-36.

Yuval-Davis, N. 1994. Women, ethnicity and empowerment. Feminism \& Psychology, 4(1): 179-197. 